\title{
Prevalence of overweight and underweight in children and adolescents in districts of Gdańsk
}

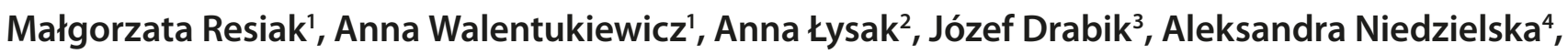 \\ Marek Jankowski ${ }^{4}$, Paweł Skonieczny ${ }^{5}$ \\ ${ }^{1}$ Department of Health Promotion, Gdańsk University of Physical Education and Sport \\ ${ }^{2}$ Department of Physiotherapy, Gdańsk University of Physical Education and Sport \\ ${ }^{3}$ University of Bydgoszcz \\ ${ }^{4}$ The Centre for the Promotion of Child Health and Fitness in Gdańsk \\ ${ }^{5}$ Department of Informatics and Statistics, Gdańsk University of Physical Education and Sport
}

Resiak M, Walentukiewicz A, Łysak A, Drabik J, Niedzielska A, Jankowski M, Skonieczny P. Prevalence of overweight and underweight in children and adolescents in districts of Gdańsk. J Pre-Clin Clin Res. 2014; 8(1): 23-26.

\begin{abstract}
Introduction. Neighbourhood impact on health has been the subject of many studies. They demonstrated that the health status of both adults and children depends, among other things, on the local environment. In turn, obesity in children and adolescents remains a major health problem in developed countries. The aim of this study was to determine the prevalence of overweight and underweight in children and adolescents (6-18-years-old) studying in schools located in different districts of Gdańsk, northern Poland.

Material and method. The study was conducted in the 2008-2009 school year in the 6th largest city in Poland - Gdańsk (456,967 inhabitants). The study group comprised 25,609 children and adolescents, including 13,000 boys and 12,609 girls. The international standard IOTF (International Obesity Task Force) was used to determine overweight and underweight. Results. The incidence of overweight in the group was $19.15 \%$, and of underweight $10.83 \%$. Differences in the prevalence of these anomalies between particular Gdańsk districts were statistically significant $(p=0.0000)$. Underweight was observed in $12.32 \%$ of the examined girls and in $9.39 \%$ of boys. The statistically significant (chi2 test) prevalence of overweight and underweight depending on the district needs further clarification.

Conclusion. Knowledge of these determinants is essential for creating effective health promotion programmes. It seems that in searching for determinants in future studies, the influence of the contextual factor should be considered.
\end{abstract}

\section{Key words}

childhood and adolescent underweight and overweight, neighbourhood

\section{INTRODUCTION}

Neighborhood impact on health has been the subject of many studies. They demonstrated that the health status of both adults and children depends, among others, on the local environment $[1,2]$. In turn, obesity in children and adolescents remains a major health problem in developed countries $[3,4]$. Studies on obesity deal with its closer and further consequences, but also with individual, social and economic determinants. Individual risk factors are identified $[5,6]$ and have both genetic, behavioral and socioeconomic background $[6,7]$. Describing the epidemiological situation, authors usually indicate socio-economic factors, arguing that a low status is a risk factor for obesity in childhood and adulthood [8]. This relationship can also be determined by the level of developed countries (depending on the country), e.g. in highly developed countries there is a relationship between lower SES and larger body size; in the medium-and developing countries it is associated with income and material possessions [9]. Some authors argue that the relationship between neighborhood and obesity is greater than one designated by an individual socioeconomic position [10], although there are those who believe that the environmental impact on the prevalence of obesity in adolescence is lower [11].

Address for correspondence: Anna Łysak, University of Physical Education and Sport, Kazimierza Górskiego 1, 80-336 Gdańsk, Poland

e-mail: niuta6@wp.pl

Received: 2 April 2014; accepted: 24 April 2014
The prevalence of underweight in developed countries is much smaller than of overweight. However, this is a big health problem in developing countries. The study on Polish 15 -year-olds conducted as part of the HBSC project found an influence of the local environment status on both over- and underweight [12].

Objective. The aim of this study was to determine the prevalence of overweight and underweight among children and adolescents learning at schools located in different districts of Gdansk.

\section{MATERIALS AND METHOD}

The study used data collected as part of research programs: the Centre for Health Promotion and Fitness Programs for Children in Gdańsk: "healthy pupil", "healthy heart of Gdansk pupils" and "health weight" (http://www.opzisdz. $\mathrm{pl} / /$ artykuly/k1,7,programy/), and the Gdańsk University of Physical Education and Sport project: "physical activity of human beings at different ages for health and the quality of life" (http://www.awf.gda.pl/index.php?id=103).

The study was conducted in the 2008/2009 school year in the 6th largest city in Poland - Gdansk (456,967 inhabitants), where 160 state educational institutions conduct educational activities, of which $143(89.37 \%)$ were included in the analysis. The study involved 25,609 children and adolescents, 
including 13,000 boys (50.76\%) and 12,609 girls (49.24\%) aged 6-18 years. The group involved in the study constitute about $50 \%(51.37 \%)$ of this age group in the Gdansk population. Calendar age (chronological, certificate), i.e. the time from birth to the time of the study [13] was calculated within an accuracy of 0.01 years by subtracting the number of completed years from the date of the study. This allowed classifying subjects into appropriate age categories $6-18$ years [14]. The breakdown of subject into age groups was made according to one of the proposals adopted in the literature [5]. Thus, the group of 6-year-olds comprised children in the range of 5.50-6.49, and it was respectively done in other age groups. Trained medical staff made measurements of body height and weight according to the applicable rules [14]. On the basis of measurements, for which SECA 217 stadiometer and body composition analyzer Tanita SC 330 S were used, the body mass index (BMI) was calculated. The prevalence of underweight and overweight, according to the IOTF definition, was determined with the use of LMSGrowth software. Defining overweight and underweight was made with a use of an international standard developed on the basis of centile curves for the body mass index depending on age and gender in conjunction with the relevant limit values applicable to adults, namely the body mass index equal to and greater than $25 \mathrm{~kg} / \mathrm{m}^{2}$ for overweight [15] and $18.5 \mathrm{~kg} / \mathrm{m}^{2}$ and less for to recognize underweight [16].

Statistical analysis. Performed using the statistical package STATISTICA v.10. An assessment of the prevalence of underand overweight among pupils of schools in the districts of Gdansk was made by means of the chi-square test.

\section{RESULTS}

The incidence of overweight in the group was $19.15 \%$, and of underweight $10.83 \%$ (tab. 1). Differences in the prevalence of these anomalies between particular Gdansk districts were statistically significant $(\mathrm{p}=0.0000)$. Boys were more often characterized by overweight while girls by underweight. The prevalence of overweight and obesity among boys was $20.82 \%$, and $17.43 \%$ among girls. Underweight was observed in $12.32 \%$ of the examined girls and in $9.39 \%$ of the boys. The difference of about 3\% was statistically significant $(\mathrm{p}=0.0000)$. The highest percentage of overweight respondents occurred in the districts Aniołki (24.66\%) and Przymorze Małe (24.64\%), in which almost every fourth subject was characterized by overweight. The largest proportion of overweight and obese girls was found in the districts Aniołki (25\%) and Matarnia (21.51\%), while among boys in the districts Przymorze Małe (28.62\%) and Nowy Port (24.87\%). Kokoszki/Jasień is the district characterized by the lowest percentage of underweight among female pupils (2.56\%) and Piecki Migowo among male pupils (4.91\%) from schools participating in the study. Variation in the prevalence of abnormal weight in the studied districts proved was statistically significant both among girls $(\mathrm{p}=0.00018)$ and boys $(p=0.00159)$. The greatest difference in the extreme incidence of overweight in the districts was $14.55 \%$, and in underweight $7.59 \%$. Gender diversity was $22.12 \%$ for boys and $14.58 \%$ for girls in terms of overweight and $9.09 \%$ for boys and $19.66 \%$ for girls in terms of underweight. The most severe simultaneous presence of over- and underweight was found
Table 1. Prevalence of underweight, normal weight and overweight in districts of Gdańsk

\begin{tabular}{|c|c|c|c|}
\hline \multirow{2}{*}{$\begin{array}{l}\% \text { of pupils in the districts } \\
\text { in BMI categories }\end{array}$} & \multicolumn{3}{|c|}{ total } \\
\hline & $\begin{array}{l}\text { under- } \\
\text { weight }\end{array}$ & norm & $\begin{array}{c}\text { over- } \\
\text { weight }\end{array}$ \\
\hline Młyniska/Przeróbka/Stogi & 7.59 & 74.05 & 18.35 \\
\hline Orunia-Św.Wojciech/Lipce/Olszynka & 12.72 & 71.22 & 16.06 \\
\hline Kokoszki/Jasień & 8.99 & 80.90 & 10.11 \\
\hline Wrzeszcz Górny/Strzyża & 9.96 & 69.83 & 20.21 \\
\hline Letnica & 14.43 & 70.10 & 15.46 \\
\hline Wrzeszcz Dolny & 10.30 & 69.46 & 20.24 \\
\hline Śródmieście & 10.33 & 68.93 & 20.73 \\
\hline Oliwa & 11.46 & 70.81 & 17.73 \\
\hline Siedlce & 14.56 & 68.65 & 16.79 \\
\hline Chełm & 10.83 & 72.18 & 16.99 \\
\hline Zaspa Rozstaje & 9.86 & 70.71 & 19.44 \\
\hline Suchanino & 11.50 & 71.08 & 17.42 \\
\hline Nowy Port & 9.13 & 69.58 & 21.29 \\
\hline Przymorze Wielkie & 10.16 & 70.38 & 19.46 \\
\hline Górki Zachodnie & 13.88 & 66.59 & 19.52 \\
\hline Żabianka-Wejhera-Jelitkowo-Tysiąclecia & 10.79 & 71.35 & 17.86 \\
\hline VII Dwór & 10.19 & 73.00 & 16.80 \\
\hline Piecki Migowo & 6.97 & 73.03 & 20.00 \\
\hline Brętowo & 11.21 & 70.07 & 18.72 \\
\hline Zaspa Młyniec & 9.80 & 68.71 & 21.49 \\
\hline Przymorze Małe & 13.31 & 62.05 & 24.64 \\
\hline Matarnia & 12.36 & 66.76 & 20.88 \\
\hline Brzeźno & 13.04 & 66.39 & 20.57 \\
\hline Osowa & 12.58 & 70.45 & 16.97 \\
\hline Wyspa Sobieszewska & 10.87 & 73.91 & 15.22 \\
\hline Ujeścisko-Łostowice & 6.80 & 76.07 & 17.13 \\
\hline Aniołki & 11.66 & 63.68 & 24.66 \\
\hline
\end{tabular}

B/G - comparison of underweight, the norm and overweight between boys and girls in the districts

in the districts of Aniołki, Przymorze Małe and Wrzeszcz Dolny (tab.2). Geographical location of the district remained without effect on the incidence of abnormalities of the body mass index (BMI).

\section{DISCUSSION}

Statistically significant differences in the incidence of underweight and overweight were found in children and adolescents, depending on the district of Gdansk. Polish studies on 15-year-olds conducted as part of the HBSC project showed that local environment adversely influences overweight and underweight [12]. In boys, the low status of the local environment was a factor determining an increased incidence of overweight and obesity, while 15-year-old girls from areas oflow intensity of problems in the local environment were more exposed to underweight [12]. The studies also found a higher likelihood of overweight and obesity in boys and of underweight in girls. Similar observations have been made in the studies presented here. To interpret the results, we need to answer the question of whether the mechanism 
Table 2. The prevalence of underweight, normal weight and overweight by gender in Gdańsk district

\begin{tabular}{|c|c|c|c|c|c|c|c|}
\hline \multirow[b]{2}{*}{$\begin{array}{l}\% \text { of pupils in the districts } \\
\text { in BMI categories }\end{array}$} & \multicolumn{3}{|c|}{ boys } & \multicolumn{3}{|c|}{ girls } & \multirow{2}{*}{$\begin{array}{c}\mathrm{B} / \mathrm{G} \\
\frac{0}{\frac{2}{\pi}} \\
\stackrel{2}{2} \\
0\end{array}$} \\
\hline & $\begin{array}{l}\frac{1}{\frac{1}{2}} \\
\frac{0}{0} \\
\frac{5}{2} \\
\frac{0}{2}\end{array}$ & ह્ํำ & 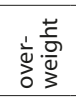 & 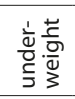 & $\stackrel{\xi}{\varrho}$ & 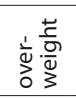 & \\
\hline Młyniska/Przeró & 10.71 & 71.43 & 17.86 & 4.05 & 77.03 & 18.92 & 0.28816 \\
\hline $\begin{array}{l}\text { Orunia-Św.Wojciech/ } \\
\text { Lipce/Olszynka }\end{array}$ & 13.02 & 68.49 & 18.49 & 12.40 & 74.10 & 13.50 & 0.15131 \\
\hline Kokoszki/Jasień & 14.00 & 80.00 & 6.00 & 2.56 & 82.05 & 15.38 & 0.07779 \\
\hline Wrzeszcz Górny/Strzyża & 9.81 & 67.11 & 23.08 & 10.17 & 73.56 & 16.27 & 0.00059 \\
\hline Letnica & 7.69 & 75.00 & 17.31 & 22.22 & 64.44 & 13.33 & 0.12502 \\
\hline Wrzeszcz Dolny & 8.28 & 69.52 & 22.20 & 12.50 & 69.39 & 18.11 & 0.00186 \\
\hline Śródmieście & 8.96 & 68.54 & 22.50 & 11.86 & 69.38 & 18.77 & 0.00304 \\
\hline Oliwa & 9.45 & 71.41 & 19.13 & 13.35 & 70.24 & 16.40 & 0.01689 \\
\hline Siedlce & 12.82 & 67.86 & 19.33 & 16.34 & 69.46 & 14.19 & 0.05522 \\
\hline Chełm & 8.90 & 72.20 & 18.90 & 12.83 & 72.15 & 15.02 & 0.00204 \\
\hline Zaspa Rozstz & 9.77 & 69.74 & 20.49 & 9.93 & 71.60 & 18.47 & 0.69651 \\
\hline Suchanino & 10.34 & 71.19 & 18.47 & 12.60 & 70.97 & 16.43 & 0.35281 \\
\hline Nowy Port & 7.18 & 67.95 & 24.87 & 11.03 & 71.18 & 17.79 & 0.01712 \\
\hline Przymorze Wielkie & 8.60 & 71.32 & 20.08 & 11.40 & 69.64 & 18.96 & 0.15513 \\
\hline Górki Zachodnie & 13.57 & 66.97 & 19.46 & 14.17 & 66.25 & 19.58 & 0.98074 \\
\hline $\begin{array}{l}\text { Żabianka-Wejhera- } \\
\text { Jelitkowo-Tysiąclecia }\end{array}$ & 9.13 & 70.72 & 20.15 & 12.48 & 71.98 & 15.55 & 0.05265 \\
\hline VII Dwór & 9.69 & 70.92 & 19.39 & 10.78 & 75.45 & 13.77 & 0.35887 \\
\hline Piecki Migowo & 4.91 & 73.13 & 21.96 & 9.02 & 72.94 & 18.04 & 0.04525 \\
\hline Brętowo & 10.34 & 70.67 & 18.99 & 12.10 & 69.45 & 18.44 & 0.75666 \\
\hline Zaspa Młyniec & 7.69 & 68.97 & 23.33 & 11.60 & 68.49 & 19.91 & 0.10927 \\
\hline Przymorze Małe & 11.31 & 60.07 & 28.62 & 15.38 & 64.10 & 20.51 & 0.05481 \\
\hline Matarnia & 10.94 & 68.75 & 20.31 & 13.95 & 64.53 & 21.51 & 0.61524 \\
\hline Brzeźno & 9.87 & 68.61 & 21.52 & 16.67 & 63.85 & 19.49 & 0.01418 \\
\hline Osowa & 9.26 & 72.91 & 17.83 & 15.88 & 68.01 & 16.11 & 0.01157 \\
\hline Wyspa Sobieszewska & 6.82 & 72.73 & 20.45 & 14.58 & 75.00 & 10.42 & 0.24542 \\
\hline Ujeścisko-Łostowice & 8.12 & 78.17 & 13.71 & 5.50 & 74.00 & 20.50 & 0.14192 \\
\hline Aniołki & 8.13 & 67.48 & 24.39 & 16.00 & 59.00 & 25.00 & 0.16854 \\
\hline
\end{tabular}

$\mathrm{B} / \mathrm{G}$ - comparison of underweight, the norm and overweight between boys and girls in the districts

of the impact of the local environment in Gdansk has both a structural and a contextual factor [17]. The latter seems to be indisputable (water and air quality, transport, the amount of green areas and safety). In a study evaluating the quality of life of adults in Gdańsk districts conducted on behalf of the Gdansk City Council by the Implementation of Sociological Research Laboratory at Gdansk University on a sample of 1,000 persons (http://s-trojmiasto.pl/download/1/ Prezentacja\% 20dla\% 20UM.pdf), which took into account developed retail space, transport links, health care, financial and housing conditions, sense of safety, nature and the natural environment, sports and recreation infrastructure and cultural offer of the city, the lowest values of index of the quality of life was recorded in districts in which the present study showed the highest prevalence of underweight. In turn, the highest proportions of overweight occurred in the districts in which the feeling of safety was the lowest in the study of the quality of life. A study of Canadian 10-11-yearolds showed a lower risk of overweight and obesity in children living in an environment with an easy access to playgrounds, parks, recreation facilities and shops (shops have healthier diets). However, there was no simultaneous correlation between overweight and obesity and a sense of safety; only taking up PA without a coach by the children was dependent on that sense [18]. Lumeng et al. found a significant correlation between parents' perception of insecurity and the prevalence of overweight in 7-year-old children [19]. The high prevalence of overweight in children and adolescents (over 20\%) was also found in some districts of Gdansk with well-developed recreation and sports infrastructure (Zaspa Młyniec, Przymorze Małe). Cochrane et al. reported no clear positive impact of the local environment on regular physical activity of people aged over 15 years [20]. An assessment of the impact of the contextual factor, assuming that people who live in the neighborhood have a similar social status (in terms of education and income) and belong to the same cultural group [17], is impossible in our study.

Statistically significant prevalence of overweight and underweight depending on the district found in our study needs further clarification. In some areas less than $2 / 3$ of the studied population of children and adolescents have reached the desired weight. Knowledge of these determinants is essential to create effective health promotion programs [19], especially since the influence possibilities of programs directed solely to the family are limited [21]. It seems that searching for determinants in future studies one should consider the influence of the contextual factor.

\section{REFERENCES}

1. Moudon AV, Cook AJ, Ulmer J, Hurvitz PM, Drewnowski A. A Neighborhood Wealth Metric for Use in Health Studies. Am J Prev Med. 2011; 41(1): 88-97.

2. Berry TR, Spence JC, Blanchard C, et al. Changes in BMI over 6 years: the role of demographic and neighborhood characteristics. Int J Obes. 2010; 34(8): 1275-1283.

3. Olds T, Maher C, Shi ZM, et al. Evidence that the prevalence of childhood overweight is plateauing: data from nine countries. Int J Pediatr Obes. 2011; 6(5-6): 342-360.

4. Lacy K, Kremer P, de Silva-Sanigorski A, et al. The appropriateness of opt-out consent for monitoring childhood obesity in Australia. Pediatr Obes. 2012; 7(5): 62-67.

5. Monasta L, Batty GD, Cattaneo A, et al. Early-life determinants of overweight and obesity: a review of systematic reviews. Obes Rev. 2010; 11(10): 695-708.

6. Harrington DW, Elliott SJ. Weighing the importance of neighbourhood: A multilevel exploration of the determinants of overweight and obesity. Soc Sci Med. 2009; 68(4): 593-600.

7. Koupil I, Toivanen P. Social and early-life determinants of overweight and obesity in 18-year-old Swedish men. Int J Obes. 2008; 32(1): 73-81.

8. Tamayo T, Herder C, Rathmann W. Impact of early psychosocial factors (childhood socioeconomic factors and adversities) on future risk of type 2 diabetes, metabolic disturbances and obesity: a systematic review. BMC Public Health 2010; 10: 525.

9. McLaren L. Socioeconomic status and obesity. Epidemiol Rev. 2007; 29: $29-48$

10. MacFarlane AM, Abbott GR, Crawford DA, Ball K. Sociodemographic and behavioural correlates of weight status among women with children living in socioeconomically disadvantaged neighbourhoods. Int J Obes. 2009; 33(11): 1289-1298.

11. Silventoinen K, Rokholm B, Kaprio J, Sorensen TA. The genetic and environmental influences on childhood obesity: a systematic review of twin and adoption studies. Int J Obes. 2010; 34(1): 29-40.

12. Oblacińska A KH, Mazur J. Socjoekonomiczne uwarunkowania dysharmonii rozwoju fizycznego młodzieży 15-letniej w Polsce. In, Med Wieku Rozw. 2008; 12: 549-557 (in Polish).

13. Malinowski A BW. Podstawy antropometrii. Metody, techniki, normy. Warszawa: PWN; 1997 (in Polish).

14. Malina RM BC. Growth maturation and physical activity. Champaign: Human Kinetics; 1991. 
15. Cole TJ, Bellizzi MC, Flegal KM, Dietz WH. Establishing a standard definition for child overweight and obesity worldwide: international survey. Br Med J. 2000; 320(7244): 1240-1243.

16. Cole TJ, Flegal KM, Nicholls D, Jackson AA. Body mass index cut offs to define thinness in children and adolescents: international survey. $\mathrm{Br}$ Med J. 2007; 335(7612): 194-197.

17. Macintyre S, Ellaway A, Cummins S. Place effects on health: how can we conceptualise, operationalise and measure them? Soc Sci Med. 2002; 55(1): 125-139.

18. Veugelers P, Sithole F, Zhang S, Muhajarine N. Neighborhood characteristics in relation to diet, physical activity and overweight of Canadian children. Int J Pediatr Obes. 2008; 3(3): 152-159.
19. Lumeng JC, Appugliese D, Cabral HJ, Bradley RH, Zuckerman B. Neighborhood safety and overweight status in children. Arch Pediatr Adolesc Med. 2006; 160(1): 25-31.

20. Cochrane T, Davey RC, Gidlow C, et al. Small Area and Individual Level Predictors of Physical Activity in Urban Communities: A Multi-Level Study in Stoke on Trent, England. Int. J. Environ. Res. Public Health. 2009; 6(2): 654-677.

21. Grow HMG, Cook AJ, Arterburn DE, et al. Child obesity associated with social disadvantage of children s neighborhoods. Soc Sci Med. 2010; 71(3): 584-591. 